\title{
INFLUENCE OF GLUCOSE AND PEPTONE ON THE MYCELIAL GROWTH OF OYSTER MUSHROOM (Pleurotus ostreatus)
}

\author{
NASHWAN Y. EDO \\ Dept. of Horticulture, College of Agricultural Engineering Sciences, University of Duhok, \\ Kurdistan Region-Iraq
}

(Received: May 25, 2021; Accepted for Publication: August 1, 2021)

\begin{abstract}
This present study was carried out to investigate the effect of glucose concentrations $\left(5,10\right.$, and 15) $\mathrm{g} . \mathrm{l}^{-1}$ as carbohydrate source and peptone $(0,2,4$, and 6$){\mathrm{g} . \mathrm{I}^{-1}}^{1}$ as nitrogen source on mycelial growth, colony diameter, growth period, and mycelial morphology of Pleurotus ostreatus. The results indicated that the

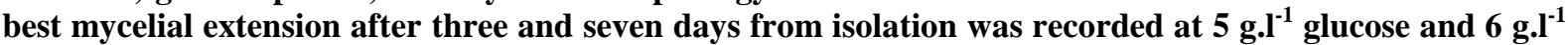
peptone whereas the lower growth of colony diameter recorded at $15 \mathrm{~g} . \mathrm{l}^{-1}$ glucose and in the control plates of peptone. Nevertheless, complete colonization of mycelial growth period was obtained after six days of incubation between lower concentration of glucose with all concentrations of peptone and between $10 \mathrm{g.l}{ }^{-1}$ glucose with $6 \mathrm{~g} . \mathrm{I}^{-1}$ peptone, while concentration $15 \mathrm{~g} . \mathrm{I}^{-1}$ glucose plus control or $2 \mathrm{~g} . \mathrm{I}^{-1}$ peptone were fully colonized after ten days from colony growth. However, the best interactions between glucose at

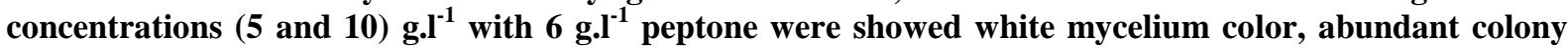
growth, high density mycelium and cottony texture as mycelial morphology characters for oyster mushroom.
\end{abstract}

KEYWORDS: Pleurotus ostreatus, Oyster Mushroom, Potato Dextrose Agar, Glucose, Peptone, Mycelial Growth.

\section{INTRODUCTION}

$\mathbf{O}$ yster mushroom (Pleurotus ostreatus) is one of the four important species based on their production and demand (Martinez and Lopez, 2010). Pleurotus ostreatus belongs to the Pleurotaceae family within the order Agaricales (Thorn et al., 2000). P. ostreatus is distributed throughout temperate forests of the northern hemisphere including Asia, Europe, and North America. In addition, the presence of $P$. ostreatus has been confirmed in South America (Zervakis and Balis, 1996).

The nutritional benefits of mushrooms have long been appreciated in the traditional medicine of many cultures and have been studied for their anti-cancer effects (Tong et al., 2009). In general, mushrooms can be used as a fresh food as well as for industrial purposes. The most commonly and easily cultivated mushrooms in Iraq and Kurdistan region are oyster mushrooms but their spawn exported from other countries, while the cultivation of this important mushroom has not been very common.

Many factors should be considered during spawn production particularly mycelial growth. Generally, there are several factors that minimizing the period of mycelial colonization and obtaining thick mushroom mycelia with fast growth rate. Those factors include culture kinds, carbon to nitrogen ratio, carbon source, nitrogen source, temperature, $\mathrm{pH}$, plant growth regulators and some other factors ( $\mathrm{Lu}, 2009)$. However, the effect of culture media on the mycelial growth of oyster mushrooms strains with the addition of glucose and peptone were the most suitable for mycelium growth (Pereima, 2017). Consequently, Nwokoye et al., (2010) investigated the mycelial growth requirements of Pleurotus ostreatus, they used different kinds of carbon and nitrogen sources including glucose and peptone, the results shown that glucose significantly enhanced mycelial growth and peptone improved the greatest mycelial growth as a nitrogen source.

Therefore, the present study is investigating the impact of different concentrations of glucose and peptone on the mycelial growth and morphology characters of oyster mushroom, this will provide basic knowledge and techniques required for mycelial growth. In addition, it is the first introduction of spawn culture and production in Iraqi Kurdistan in a simple way. Thus, the recent study will provide better 
opportunities for mushroom production in Iraqi Kurdistan with lower costs. Furthermore, it will provide extra job opportunists for farmers and graduated students as well as providing a substantial product when the price of other products decreases.

\section{MATERIALS AND METHODS}

This experiment was carried out at University of Duhok, College of Agricultural Engineering Sciences, Kurdistan Region-Iraq.

\section{Preparation of culture media}

The pure culture used as substrate for isolation of cultivated oyster mushrooms which is obtained on the table (1). This medium was used as a substrate for isolation and sub-culture or regeneration agar medium for study treatments.

Table (1): The basal culture (PDA*) in one litre of distilled water for P. ostreatus isolation.

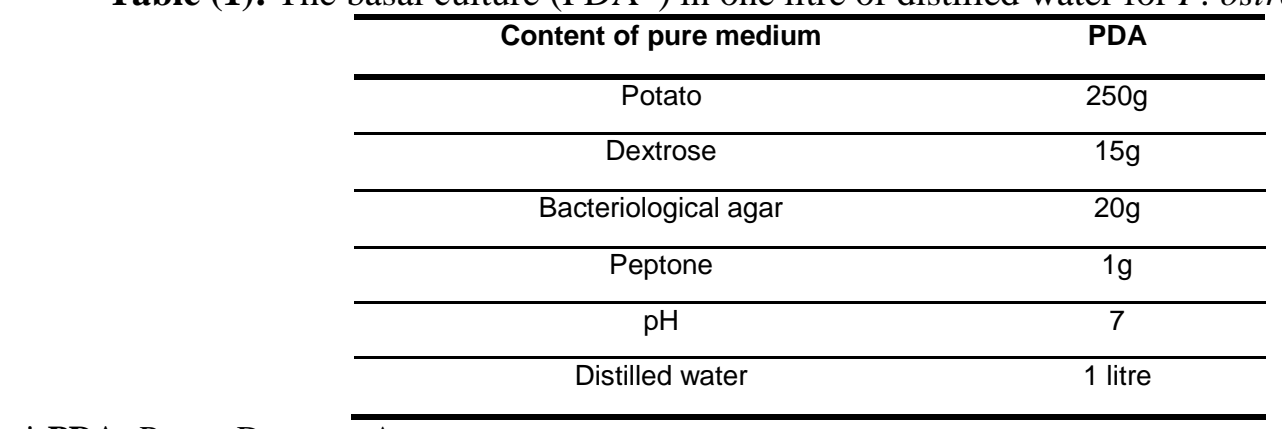

* PDA: Potato Dextrose Agar

\section{Procedure}

The potato dextrose agar (PDA) medium was prepared by boiling $250 \mathrm{~g}$ of sliced unpeeled potato in $600 \mathrm{ml}$ of distilled water for 20 minutes then added enough water to infusion of potato for dissolving $20 \mathrm{~g}$ of bacteriological agar and $15 \mathrm{~g}$ dextrose plus $1 \mathrm{~g}$ peptone and completed the volume to $1000 \mathrm{ml}$ by distilled water, subsequently $\mathrm{pH}-7$ was adjusted via electronic $\mathrm{pH}$ meter (Type $\mathrm{BP} 3001$ ) using $\mathrm{HCl}$ and $\mathrm{NaOH}$. The medium was sterilized using autoclave at 15 lbs pressure $121^{\circ} \mathrm{C}$ for 20 minutes. After this process, $10 \mathrm{ml}$ of the sterile medium were poured into plastic petri dishes $(70 \times 15 \mathrm{~mm})$ and allowed to solidified, then incubated for 24 hours at $25^{\circ} \mathrm{C}$ to ensure the purity of the media from any possible contaminants (GuadarramaMendoza et al., 2014).

For tissue culture, one day aged, fresh and a healthy mushroom was obtained from local distributor. However, under aseptic conditions mushroom was isolated according to (Singh et $a l ., 2011)$, then incubated at optimal temperature $28^{\circ} \mathrm{C}$ for mycelium growth of oyster mushroom (Hoa and Wang, 2015). After ten days mycelium colonies regenerated from growing edges and carefully transferred to another PDA that prepared at the same way in the table (1) and again incubated for another 10 days to obtain pure cultures of mycelium for isolation to the experimental treatments.

\section{Glucose and peptone concentrations}

In this study three concentrations of glucose $\left(5,10\right.$, and 15) g. $1^{-1}$ and four concentrations of peptone $(0,2,4$, and 6$)$ g. $1^{-1}$ were used with 3 replications and 36 experimental unit, under aseptic conditions the culture disc about $5 \mathrm{~mm}$ in diameter cut out from growing edges of pure mycelium that prepared before from the petri dishes $(70 \times 15 \mathrm{~mm})$ and transferred into the larger dishes $(90 \times 15 \mathrm{~mm})$ for each selective plate. The inoculated petri dishes were incubated aseptically at optimum temperature $28^{\circ} \mathrm{C}$ (Pereima, 2017).

\section{Colony diameter}

The diameter speed of mycelium growth $(\mathrm{mm})$ in $(90 \times 15 \mathrm{~mm})$ petri dishes was measured via electronic vernier and data were recorded at 3 and 7 days (Mbogoh et al., 2011). The experiment was arranged in RCBD design and data were analysed using IBM SPSS Statistics software, V. 25. Then, the means were compared using Duncan multiple range test at $p<0.01$ level of confidence.

\section{Mycelial morphology}

The nature of mycelia growth was recorded through visual observation after complete colonization of mycelium in petri dishes according to (Sobal et al., 2007), he states that the major characters of mycelia morphology as texture (cottony, velvety or floccose), density (high, regular or low), colour (off-white, white 
or pale pink), colony growth (scarce, regular or abundant) and growth period per days.

\section{RESULTS AND DISCUSSION}

Colony diameter: Table (2) shows that the growth of mycelium inoculation after three days, the impact of glucose at $5 \mathrm{~g} . \mathrm{l}^{-1}$ exhibited highest mycelium growth of Pleurotus ostreatus followed by 10 g.l ${ }^{-1}$, and 15 g.l ${ }^{-1}$ (Fig. 1) while there was no significantly observed between them, this is in accordance with the findings of (Neelam et al., 2013) who studied the carbon requirement on the growth of oyster mushroom, their results showed that glucose was the best carbon source, In addition, (Lishma and Lulu Das, 2015) recorded that glucose was the best carbon source among many types of sugar for mycelial growth of white button mushroom, but it is contradictory to the results of experiment conducted by (Memon et al., 2017), they shown that the effect of dextrose sugar on mycelial growth of oyster mushroom significantly recorded at 20 g. $1^{-1}$ glucose, concerning that increasing sugar concentrations more than 20 g.l ${ }^{1}$ produced fewer mycelial growth, One possible reason can be related to the unavailability of nitrogen sources in culture media. Another reason may be the inadequate amount of nitrogen sources in the media. this is confirmed by (Ma et al., 2014) who suggested that the optimum carbon to nitrogen ratio of culture media for white mushroom was 20:1 30:1.

However, the results show growth on all plates which tested and the mycelial growth diameter was seen significantly differ depending on the available of nitrogen sources in four concentrations of peptone even in control plates, this might be returned to the reasons of one gram peptone inside two subcultures of agar causes to improve growth in the control plates while only to a certain level (Fig. 1). In addition, that the best maximum diameter of mycelial growth was found in $6 \mathrm{~g} .1^{-1}$ peptone but it is not significant differences from the other concentrations except control which recorded the lowest diameter of colony growth. On the other hands, (Nwokoye et al., 2010) who reported that peptone supported the greatest mycelial growth of oyster mushroom as a nitrogen source. However, the significant interactions between glucose and peptone obtained in the lower concentration of glucose with higher concentration of peptone.

Table (2): Effect of glucose and peptone on the mycelial growth diameter $(\mathrm{mm})$ of oyster mushroom after 3 days from isolation.

\begin{tabular}{|c|c|c|c|c|c|}
\hline \multirow[t]{2}{*}{ Glucose $\mathrm{g} . \mathrm{I}^{-1}$} & \multicolumn{4}{|c|}{ Peptone g. I $^{-1}$} & \multirow[t]{2}{*}{ Means of glucose } \\
\hline & 0 & 2 & 4 & 6 & \\
\hline 5 & $24.33^{\mathrm{DC}}$ & $30.47^{\mathrm{abc}}$ & $33.54^{\text {ab }}$ & $37.01^{a}$ & $31.34^{\mathrm{a}}$ \\
\hline 10 & $22.29^{b c}$ & $25.05^{\mathrm{bc}}$ & $26.04^{\mathrm{abc}}$ & $27.87^{\mathrm{abc}}$ & $25.31^{b}$ \\
\hline 15 & $20.76^{c}$ & $23.67^{b c}$ & $23.79^{b c}$ & $27.12^{\mathrm{abc}}$ & $23.84^{b}$ \\
\hline ans of peptone & $22.46^{b}$ & $26.40^{\text {ab }}$ & $27.79^{\text {ab }}$ & $30.67^{a}$ & \\
\hline
\end{tabular}

* Means within the same column followed by the same letters are not significantly different at $\mathrm{p}<0.01$ according to Duncan's test. 


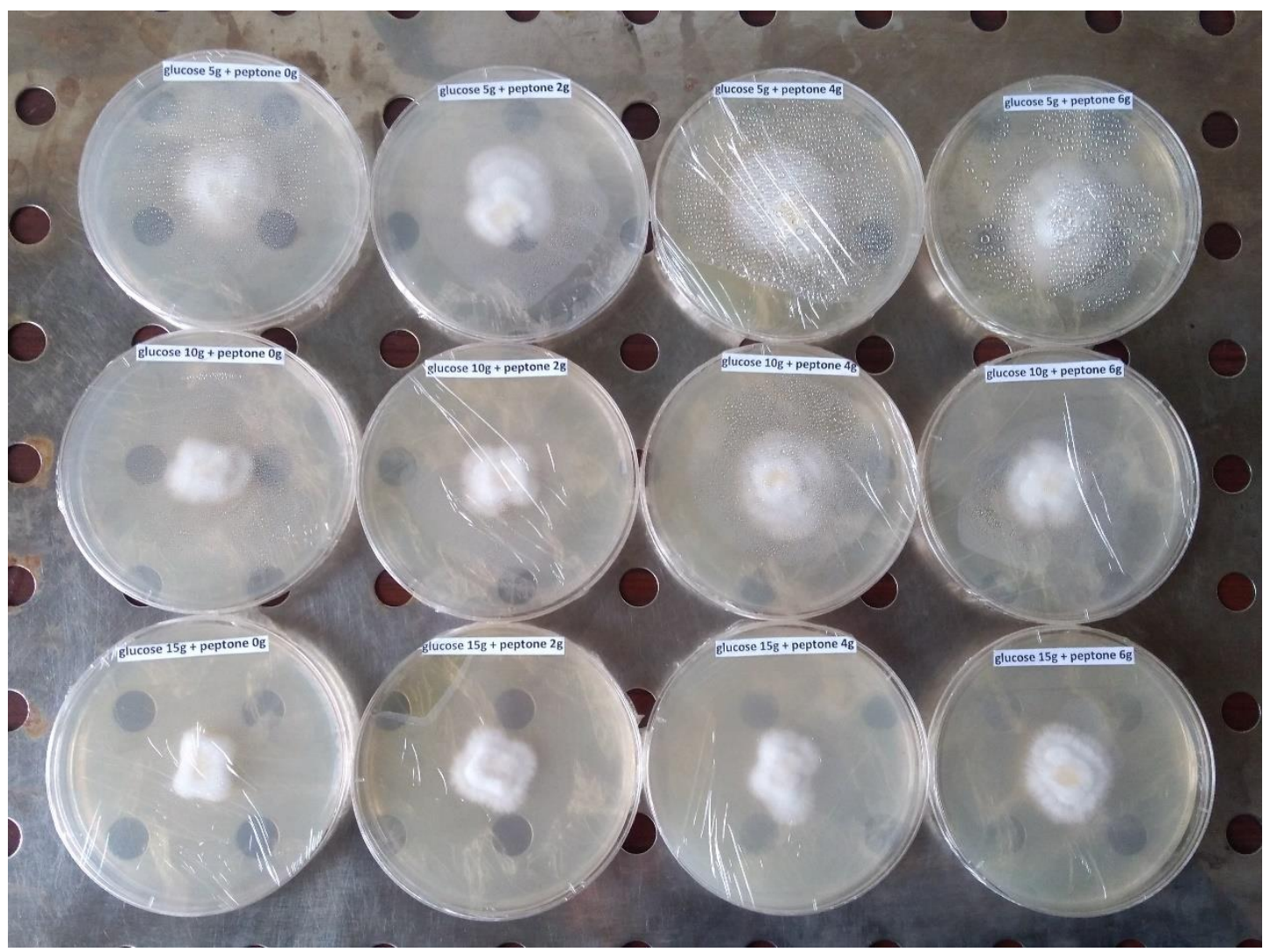

Fig. 1: Indicates that the extend of mycelial growth at 3 days after inoculation in replication one for entire plates that starting from ( $5 \mathrm{~g}$ glucose + control peptone and ended by $15 \mathrm{~g}$ glucose $+6 \mathrm{~g}$ peptone) $\mathrm{l}^{-1}$ respectively.

Colony diameter: Table (3) revealed that the growth of mycelium inoculation after seven days. Hence, the influences of glucose significantly recorded at (5 and 10) $\mathrm{g} . \mathrm{l}^{-1}$ which has maximum mycelium growth of Pleurotus ostreatus (Fig. 2). Those results agree with the findings of (Thirumalvalavan et al., 2005) that recorded glucose as better carbon sources than others and petri dishes that contain $15 \mathrm{~g} . \mathrm{l}^{-1}$ glucose obtained the minimum growth of colony diameter (Fig. 2). The effect of peptone significantly increased in the high concentration 6 g. $\mathrm{l}^{-1}$ which has higher mycelium growth, also (Ma et al., 2014) and (Lishma and Lulu Das, 2015) recorded the best sources of nitrogen was peptone after yeast and beef extract for the mycelial growth of white button mushroom. And plates that contain (0 and 2) g. $1^{-1}$ peptone had the lowest growth of colony diameter. On the other hands, (Nwokoye et al., 2010) found that peptone gradually increased mycelial dry weight of Pleurotus ostreatus until 50 g. $l^{-1}$. Consequently, after seven days from incubation the interaction between glucose and peptone significantly seen in many treatments (Fig. 2) but the better one was glucose at $5 \mathrm{~g} . \mathrm{l}^{-1}$ with the entire levels of peptone which had fully colonized petri dishes. And the lesser amount of mycelium growth recorded at concentration 15 g. l $^{-1}$ glucose + without peptone.

Table (3): Effect of glucose and peptone on the mycelial growth diameter (mm) of oyster mushroom after 7 days from isolation.

\begin{tabular}{|c|c|c|c|c|c|}
\hline \multirow[t]{2}{*}{ Glucose $\mathrm{g} . \mathrm{I}^{-1}$} & \multicolumn{4}{|c|}{ Peptone g..$^{-1}$} & \multirow[t]{2}{*}{ Means of glucose } \\
\hline & 0 & 2 & 4 & 6 & \\
\hline 5 & $87.00^{\mathrm{a}}$ & $87.00^{\mathrm{a}}$ & $87.00^{\mathrm{a}}$ & $87.00^{\mathrm{a}}$ & $87.00^{\mathrm{a}}$ \\
\hline 10 & $83.85^{\mathrm{a}}$ & $81.44^{\mathrm{ab}}$ & $83.16^{\mathrm{a}}$ & $86.00^{\mathrm{a}}$ & $83.61^{a}$ \\
\hline 15 & $63.18^{\mathrm{C}}$ & $67.18^{\mathrm{cd}}$ & $72.4^{\mathrm{bc}}$ & $79.32^{\mathrm{ab}}$ & $70.52^{b}$ \\
\hline leans of peptone & $78.01^{b}$ & $78.54^{b}$ & $80.85^{\mathrm{ab}}$ & $84.11^{\mathrm{a}}$ & \\
\hline
\end{tabular}

* Means within the same column followed by the same letters are not significantly different at $\mathrm{p}<0.01$ according to Duncan's test. 


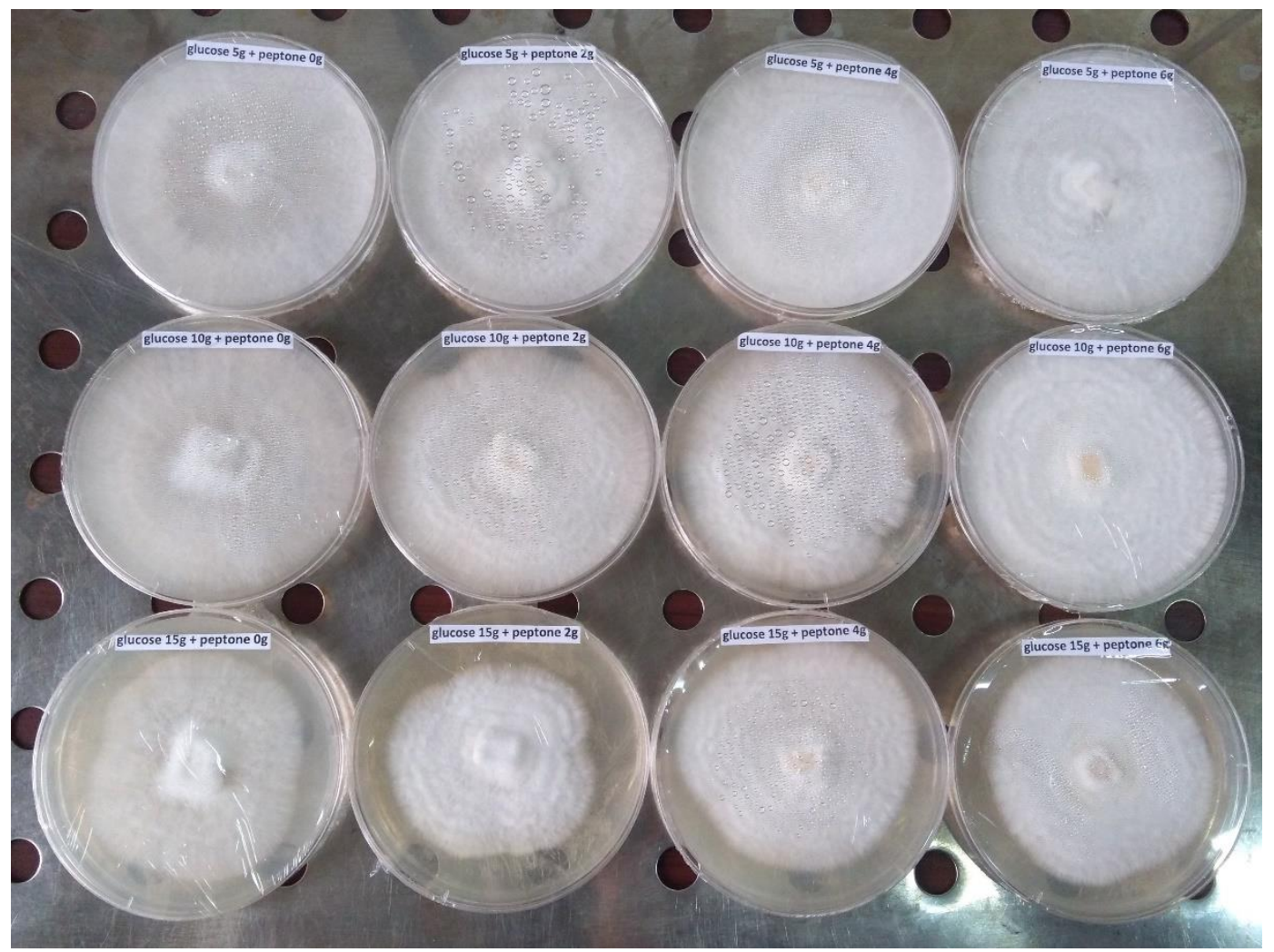

Fig. 2: Shows that the extend of mycelial growth at 7 days after inoculation in replication one for entire plates that starting from $\left(5 \mathrm{~g}\right.$ glucose + control peptone and ended by $15 \mathrm{~g}$ glucose $+6 \mathrm{~g}$ peptone) $\mathrm{l}^{-1}$ respectively.

\section{Mycelial morphology}

Mycelial colonies after 10 days of entire plates for each replication were observed white colour (Table 4) and there were no recorded significant differences among them. This might be due to in this study two subcultures of PDA used to obtain pure mycelium as substrate for isolation.

On the other hands, after complete colony growth at 6 days the best treatments $(5 \mathrm{~g}$ or $10 \mathrm{~g}$ glucose $+6 \mathrm{~g}$ peptone) $\mathrm{l}^{-1}$ were recorded abundant colony growth, high density mycelium and cottony texture (Fig. 2) and the rest treatments were highly different. The result is in agreement with (Guadarrama-Mendoza et al., 2014) who suggested that cottony mycelium of Pleurotus spp. presented significantly higher growth rates in comparison with floccose mycelium and they confirmed that cottony mycelium resulted in two various types of growth. Firstly, cottony has high density and abundant growth. Secondly, cottony texture also has regular density and regular growth as shown in table (4).

Generally, complete colonization after 6 days that showed a shortest growth period of mycelium and significantly recorded in some plates including glucose at $5 \mathrm{~g}^{-l^{-1}}$ plus all concentrations of peptone, and $10 \mathrm{~g} \cdot \mathrm{l}^{-1}$ glucose with 6 g. $\mathrm{l}^{-1}$ peptone. Whereas the interactions between 15 g..$^{-1}$ glucose + control and 2 g..$^{-1}$ peptone were fully colonized after 10 days from inoculation. 
Table (4): Effect of glucose and peptone on the mycelial morphology and growth period of oyster mushroom.

\begin{tabular}{|c|c|c|c|c|c|c|}
\hline \multirow[b]{2}{*}{ T. } & \multirow[b]{2}{*}{ Culture media I ${ }^{-1}$} & \multicolumn{4}{|c|}{ Mycelial morphology } & \multirow{2}{*}{$\begin{array}{l}\text { Growth } \\
\text { period } \\
\text { (days) }\end{array}$} \\
\hline & & $\begin{array}{l}\text { Colony } \\
\text { growth }\end{array}$ & Density & Texture & Colour & \\
\hline $\mathrm{T}_{1}$ & $5 \mathrm{~g}$ glucose $+0 \mathrm{~g}$ peptone & regular & low & velvety & white & 6 \\
\hline $\mathrm{T}_{2}$ & $5 g$ glucose $+2 g$ peptone & abundant & low & velvety & white & 6 \\
\hline $\mathrm{T}_{3}$ & $5 g$ glucose $+4 g$ peptone & regular & regular & floccose & white & 6 \\
\hline $\mathrm{T}_{4}$ & $5 \mathrm{~g}$ glucose $+6 \mathrm{~g}$ peptone & abundant & high & cottony & white & 6 \\
\hline $\mathrm{T}_{5}$ & $10 \mathrm{~g}$ glucose $+0 \mathrm{~g}$ peptone & regular & regular & velvety & white & 7 \\
\hline $\mathrm{T}_{6}$ & $10 \mathrm{~g}$ glucose $+2 \mathrm{~g}$ peptone & abundant & regular & floccose & white & 8 \\
\hline $\mathrm{T}_{7}$ & $10 \mathrm{~g}$ glucose $+4 \mathrm{~g}$ peptone & abundant & high & cottony & white & 8 \\
\hline $\mathrm{T}_{8}$ & $10 \mathrm{~g}$ glucose $+6 \mathrm{~g}$ peptone & abundant & high & cottony & white & 6 \\
\hline $\mathrm{T}_{9}$ & $15 \mathrm{~g}$ glucose $+0 \mathrm{~g}$ peptone & scarce & low & velvety & white & 10 \\
\hline $\mathrm{T}_{10}$ & $15 g$ glucose $+2 g$ peptone & scarce & high & cottony & white & 10 \\
\hline $\mathrm{T}_{11}$ & $15 g$ glucose $+4 g$ peptone & regular & regular & cottony & white & 9 \\
\hline $\mathrm{T}_{12}$ & $15 g$ glucose $+6 g$ peptone & regular & high & cottony & white & 9 \\
\hline
\end{tabular}

* Mycelial morphology recorded after complete colonization of mycelium in each plate.

\section{CONCLUSION}

In conclusion, the study shows that different levels of glucose and peptone sources can be used for mycelial growth of oyster mushroom. According to study results the mycelial growth, colony diameter and growth period were the best when decreased in the concentration of glucose, whereas increasing in the concentration of peptone causes to increase the growth rate of mycelial colony. Also improving mycelial morphology characters and complete colonization after six days for dual interaction significantly recorded between low and medium concentration of glucose with high concentration of peptone.

\section{REFERENCES}

Guadarrama-Mendoza, P. C., Valencia del Toro, G., Ramirez-Carrillo, R., Robles-Martinez, F., Yanez-Fernandez, J., Garin-Aguilar, M. E., and Bravo-Villa, G. (2014). Morphology and mycelial growth rate of Pleurotus spp. strains from the Mexican Mixtec region. Brazilian Journal of Microbiology, 45(3), 861-872.

Hoa, H. T., and Wang, C. L. (2015). The effects of temperature and nutritional conditions on mycelium growth of two oyster mushrooms (Pleurotus ostreatus and Pleurotus cystidiosus). Mycobiology, 43(1), 14-23.

Lishma, N. P., and Lulu Das. (2015). Influence of different nutrient sources on the growth of white button mushroom (Agaricus bisporus) in Kerala. International Journal of Applied and
Pure Science and Agriculture (IJAPSA). Volume 01, Issue 4, 27-30.

Lu, D. (2009). A review for cultivation and biochemistry of Agaricus bisporus. Zhejiang Edible Fungi. 17: 23-28.

Ma, Y. Guan, C. Y., and Meng, X. J. (2014). Biological characteristics for mycelial growth of Agaricus bisporus. In Applied Mechanics and Materials. Trans Tech Publications Ltd. (Vol. 508, pp. 297-302).

Martinez-Carrera, D., and Lopez-Martinez de Alva, L. (2010). History of the commercial cultivation of edible mushrooms in Mexico II: successes and failures during the period 19912009. Towards a sustainable development of the system of production-consumption of edible and medicinal mushrooms in Latin America: advances and perspectives in the XXI century, 513-551. (in Mexican).

Mbogoh, J. M., Anjichi, V. E., Rotich, F., and Ahoya, N. K. (2011). Substrate effects of grain spawn production on mycelium growth of oyster mushroom. Acta horticulturae, (911), 469-471.

Memon, A. A., Mangrio, G. S., Kaleri, A. A., Kumar, B., Khan, M., Kaleri, R., and Wahocho, N. (2017). Effect of Dextrose Sugar on the Growth and Production of Oyster Mushroom (Pleurotus ostreatus) through Tissue Culture. Journal of Basic and Applied Sciences, 13, 139-142.

Neelam, S., Chennupati, S., and Singh, S. (2013). Comparative studies on growth parameters and physio-chemical analysis of Pleurotus 
ostreatus and Pleurotus florida. Asian J. Plant Sci. Res, 3, 163-169.

Nwokoye, A. I., Kuforiji, O. O., and Oni, P. I. (2010). Studies on mycelial growth requirements of Pleurotus ostreatus (Fr.) Singer. International Journal of Basic and Applied Sciences, 10(2), 47-53.

Pereima, I. V. (2017). Stimulation of growth of species of the fungus of the genus Pleurotus (Fr.) P. Kumm. at a glucose nutrition. Biotechnologia Acta, 10(6). P. 45-52.

Singh, M. Vijay, B., Kamal, S., Wakchaure, G.C. (2011). Mushrooms Cultivation, Marketing and Consumption. Directorate of Mushroom Research (ICAR). Indian Council of Agricultural Research. Chambaghat, Solan 173213 (HP). P.32.

Sobal, M. Martinez-Carrera, D. Morales, P. and Roussos, S. (2007) Classical characterization of mushroom genetic resources from temperate and tropical regions of Mexico. Micol Apl Int 19:15-23.

Thirumalvalavan, M., Eswaran, A., Renganathan, P. and Mathan, A. (2005). Effect of various spawn substrates on Pleurotus florida. National Seminar on Emerging Trends in Plant Pathology and their Social Relevance (ETPPSR). 7-8 march 2005. Annamalai University, Annamalai Nagar. Abstract: 143.

Thorn, R. G., Moncalvo, J. M., Reddy, C. A., and Vilgalys, R. (2000). Phylogenetic analyses and the distribution of nematophagy support a monophyletic Pleurotaceae within the polyphyletic Pleurotoid-lentinoid fungi. Mycologia, 92(2), 241-252.

Tong, H., Xia, F., Feng, K., Sun, G., Gao, X., Sun, L., and Sun, X. (2009). Structural characterization and in vitro antitumor activity of a novel polysaccharide isolated from the fruiting bodies of Pleurotus ostreatus. Bioresource Technology, 100(4), 1682-1686.

Zervakis, G., and Balis, C. (1996). A pluralistic approach in the study of Pleurotus species with emphasis on compatibility and physiology of the European morphotaxa. Mycological Research, 100(6), 717-731. 
كارتيّكرنا كَلوكوزى و يييتونى لسهر كهشه كرنا مايسليهمي كقاركا سهدهفى (Pleurotus ostreatus)

يوخته

ئهث قه كولينه هاته ئهنجامدان زبو كارتيّكرنا سى خهستييّن كلوكوزى (5، 10، و 15) گم/لتر وهك

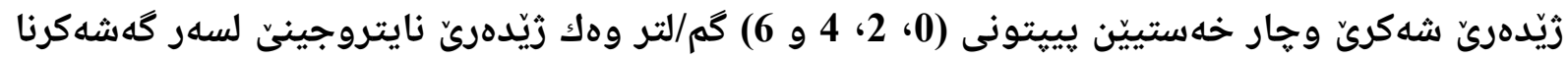

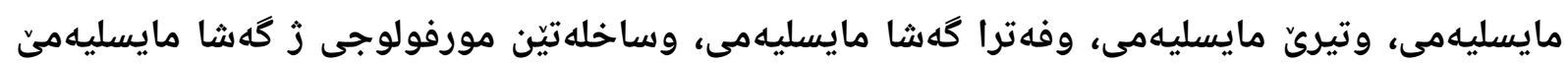

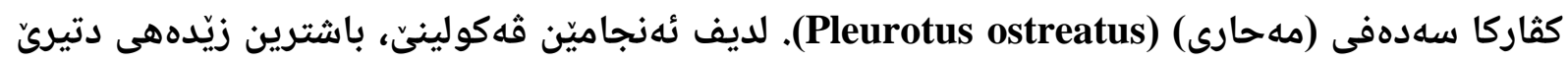

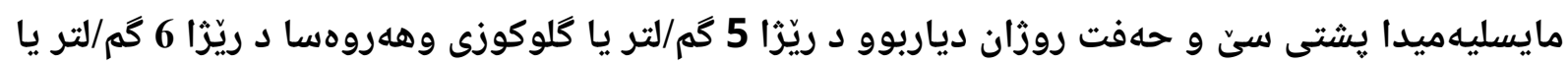

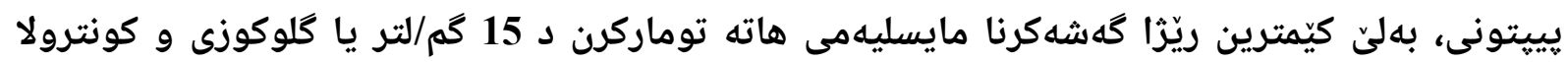

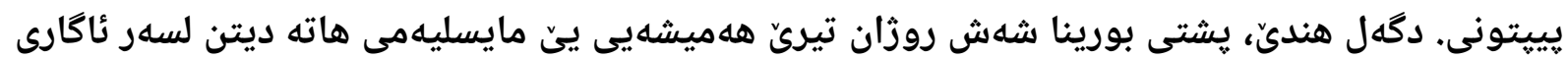

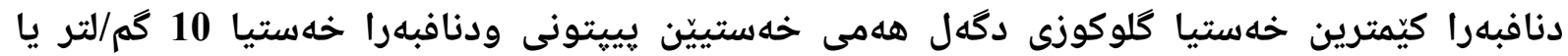
كلوكوزى دگهل 6 گم/لتر يا خهستيا يييتونى. بهلى يشتى بورينا دهه روزان تيرى مايسليهمى بتمامى هاته

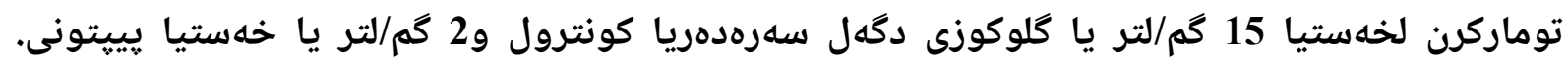
ههروهسا باشترين كارتيّكرنا ليّكدانيّن دوو قولى دنافبهرا خهستييّن كلوكوزى (5 و 10 10) كم/لتر دكهل 6

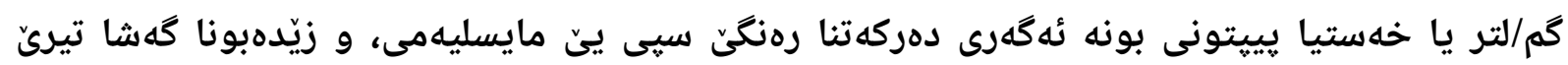

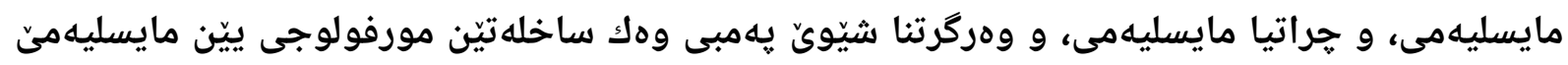

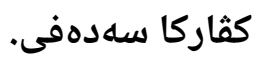

تأثير الكلوكوز والثيثتون على نمو الميسيليم لفطر المحاري (Pleurotus ostreatus)

الخلاصة أجريت هذه الدراسة للتحقق من تراكيز مختلفة من الطلوكوز (5، 10، و 15) غم/لتر كمصدر للكربوهيدرات، والثيثتون (0، 2، 4، و 6) غم/لتر كمصدر للنيتروجين على نمو الميسيليم، وقطر المستعمرة، وفترة النمو الكلي

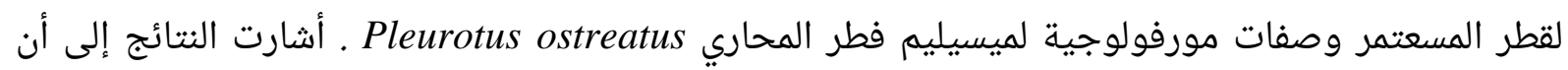
أفضل امتداد للميسيليم بعد ثلاثة و سبعة أيام من العزل تم تسجيله عند 5 غم/لتر كلوكوز و 6 غم/لتر ثيثتون

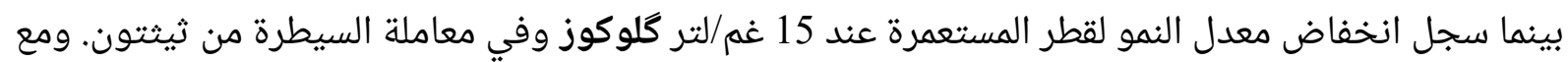

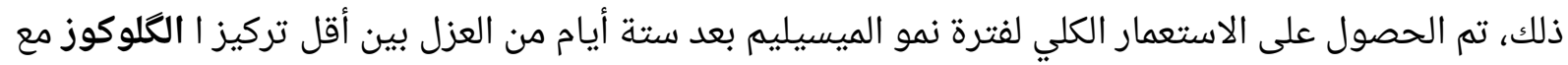
جميع تركيزات الثيثتون وبين 10 غم/لتر كلوكوز مع 6 غم/لتر ثيثتون، بينما 15 غم/لتر كلوكوز مع مع معاملة

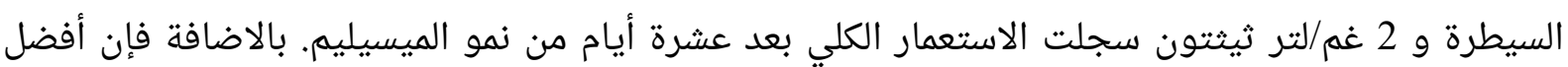
التداخلات بين كلوكوز بتركيزات (5 و 10) غم/لتر مع 6 غم/لتر ثيثتون كانت بيضاء اللون، وكثرة نمو المستعمرات، وميسيليم عالية الكثافة، ونسيج قطني كصيفات مورفولوجية لميسيليم فطر المحاري. الكلمات المفتاحية: Pleurotus ostreatus، فطر المحاري، البطاطس دكستروز أطار، كُلوكوزز، ثيثتون، نمو الميسيليم. 